\title{
KEPEMIMPINAN MOTIVASI DAN KOMPENSASI PENGARUHNYA TERHADAP KINERJA (STUDI PADA BADAN PENGELOLA PAJAK DAN RETRIBUSI DAERAH KOTA LUBUKLINGGAU SUMATERA SELATAN)
}

\author{
${ }^{1}$ Yohanes Susanto, ${ }^{2}$ Hendrik \\ ${ }^{1,2}$ Prodi Magister Manajemen, Universitas Bina Insan, Lubuklinggau \\ E-mail : ${ }^{1}$ susantoyohanes60@gmail.com, ${ }^{2}$ hendrik@ gmail.com
}

\begin{abstract}
ABSTRACK
This study aims to examine the effect of leadership, motivation and compensation on employee performance at the local tax and retribution management body in Lubuklinggau City, with a sample of 38 respondents from employees. shows, partially there is a positive and significant influence of each exogenous variable on the endogenous variables, namely the variables of leadership, motivation and compensation have an effect on employee performance, and simultaneously the four exogenous variables jointly affect employee performance. However, partially the compensation variable is more dominant in influencing employee performance. Management implication, that either simultaneously or partially each variable affects employee performance, however the most dominant variable compensation is therefore it is suggested that management pay attention to the compensation structure in order to improve performance.
\end{abstract}

Keywords : Leadership, Motivation, Compensation, Employee Performance

\begin{abstract}
ABSTRAK
Penelitian ini bertujuan untuk menguji pengaruh kepemimpinan, motivasi dan kompensasi terhadap kinerja pegawai pada badan pengelola pajak dan retribusi daerah Kota Lubuklinggau, dengan sampel sebanyak 38 responden dari pegawai, metode pada penelitian in adalah metode kuantitatif deskriptif, dengan alat statistik SPSS 24,0 Hasil penelitian menunjukkan, secara parsial terdapat pengaruh positif dan signifikan dari masing-masing variabel eksogen terhadap variabel endogen yaitu variabel kepemimpinan, motivasi dan kompensasi berpengaruh terhadap Kinerja pegawai, dan secara simultan dari ke empat variabel eksogen tersebut secara bersama-sama mempengaruhi kinerja pegawai. Namun secara parsial variabel kompensasi lebih dominan dalam mempengaruhi kinerja pegawai. Implikasi Manajemennya, bahwa baik secara simultan maupun secara parsial masing masing variabel mempengaruhi Kinerja pegawai, namun variabel Kompensasi paling dominan oleh karenanya disarankan pihak Manajemen dapat memperhatikan struktur Kompensasi guna peningkatan kinerja.
\end{abstract}

Kata kunci : Kepeimimpinan, Motivasi, Kompensasi, Kinerja Pegawai 


\section{PENDAHULUAN}

Dalam menjalankan tugas yang dibebankan, berhasil atau tidaknya suatu organisasi tergantung oleh keberhasilan dari individu pegawai masing-masing. Setiap pegawai untuk bekerja dengan baik pasti ditemukan berbagai hambatan, sehingga kinerja pegawai tersebut dapat diterima oleh lembaga organisasi. Berbagai faktor yang memengaruhi kinerja antra lain kepemimpinan, motivasi, kompensasi dan masih banyak lainnya. Saat ini kepemimpinan (leadership) telah banyak mengalami perubahan, tidak cukup hanya mengandalkan karakteristik kepribadian, dan karisma sajaa, namun kepemimpinan adalah kepribadian yang bervariasi dalam menjalankan tugas pekerjaan bersama-sama orang lain dengan inisiatif secara fisik dan mental untuk mencapai tujuan organisasi. Menurut Fahmi (2014:58)Kepemimpinan merupakan suatu ilmu yang mengkaji secara komprehensif tentang bagaimana mengarahkan, mempengaruhi, dan mengawasi orang lain untuk mengerjakan tugas sesuai dengan perintah yang direncanakan Keberhasilan suatu organisasi tergantung dengan peran sesorang pemimpin dalam mempengaruhi bawahannya dan mampu memotivasi pegawai untuk melaksanakan tugasnya yang telah ditetapkan suatu lembaga pemerintahan. Pemimpin dalam melaksanakan lembaga organisasi memiliki peran yang sangat erat. Pemimpin harus mampu memberikan visi dan misi atau arah yang jelas kemana organisasi akan mencapai tujuannya, tidak hanya sekedar membimbing dan mengarahkan bawahanya. Permasalahanyang dihadapi oleh seorang pemimpin salah satunya adalah bagaimana meningkatkan keberhasilan sebuah organisasi dengan meningkatkan kinerja pegawai secara optimal. Dengan memberikan motivasi kinerja pegawai dapat ditingkatkan. Didalam sebuah organisasi pegawai pasti memiliki motivasi masing-masing untuk bekerja.
Dengan memberikan motivasi tambahan baik secara finansial ataupun non finansial, kinerja pegawai dapat berjalan dengan baik dan merupakan satu faktor terpenting untuk dapat meningkatkan kinerja pegawai. Motivasi adalah dorongan terhadap serangkaian proses perilaku manusia pada pencapaian tujuan. Sedangkan elemen yang terkandung dalam motivasi meliputi unsur membangkitkan, mengarahkan, menjaga, menunjukan intensitas, bersifat terus menerus dan adanya tujuan,Wibowo (2017:322) Dalam menjalankan suatu pekerjaan disebuah organisasi kompensasi merupakan salah satu hal penting yang harus diperhatikan. Hak-hak sebagai pegawai harus diterimanya setelah pengawai menjalankan kewajibannya yaituimbalan dan kompensasi. Dengan memberikan kompensasi, produktivitas dan efisiensi dapat meningkat salah satu upaya yang harus ditempuh organisasi. Untuk menciptakan kinerja pegawai kompensasi atau balas jasa juga berperan penting. Kedisiplinan pegawai akan semakin membaik apabila organisasi semakin besar balas jasa yang diberikan kepada pegawai. Menurut Sutrisno (2016:183) kompensasi adalah segala sesuatu yang diterima oleh karyawan sebagai balas jasa untuk kerja mereka Sedangkan menurut Hasibuan (2014:118) kompensasi adalah semua pendapatan yang berbentuk uang, barang langsung atau tidak langsung yang diterima karyawan sebagai imbalan atas jasa yang diberikan kepada perusahaan Untuk memenuhi kebutuhan sehari-hari pegawai, kompensasi inilah yang akan digunakan oleh pegawai. Semakin meningkat dan besar kompensasi yang diberikan kepada pegawai oleh organisasi, maka setiap pegawai akan meningkatkan kinerjanya karena kebutuhan pegawai terpenuhi. Oleh karena itu untuk meningkatkan kinerja pegawai secara optimal, maka dari itu kepemimpinan, motivasi dan kompensasi perlu perhatikan. Berdasarkan hasil observasi awal atau pengamatan sementara pada Badan 
Pengelola Pajak dan Retribusi Daerah Kota Lubuklinggau. Dari segi kepemimpinan terdapat permasalahan, Masih lemahnya kemampuan pimpinan dalam memberikan motivasi, kurangnya memperhatikan masukan atau saran dari bawahan dalam mengambil keputusan, interaksi antara pimpinan terhadap bawahanya kurang, dalam memberikan arahan kepada pegawai masih kurang, dan kurangnya evaluasi sehingga dalam mencapai tujuan masih belum optimal. Dari segi motivasi, terdapat permasalah, berupa kurangnya pegawai memotivasi dirinya untuk menyelesai tugas yang dibebankan, kurangnya apresiasi dan pujian dari atasan terhadap bawahan saat bawahan mampu menyelesaikan tugas yang diberikan, kurangnya motivasi kerja pegawai untuk berprestasi dan kurangya motivasi pegawai untuk kreatif dalam menyelesaikan pekerjaan secara optimal. Dari segi kompensasi, terdapat permasalah masih belum meratanya pemberian kompensasi kepada pegawai, Masih adanya kesenjangan penerimaan insentif yang diterima oleh pegawai, yang menyebabkan timbulnya kecemburuan sosial di antara pegawai. Dari segi kinerja, terdapat permasalah belum optimalnya kinerja pegawai yang di anggap baik dan memenuhi standar, kurang optimalnya penyelesai tugas sehari-hari dan hasil kinerja pegawai belum mencapai hasil yang optimal.

\section{TINJAUAN PUSTAKA}

\subsection{Kinerja}

Menurut (Wibowo 2017:2) Kinerja adalah hasil dari pekerjaan berkaitan dengan tujuan organisasi seperti kualitas, efisiensi, dan kriteria lain dari efektivitas Menurut Fahmi (2014:226) Kinerja adalah hasil yang diperoleh oleh suatu organisasi baik organisasi tersebut bersifat profit oriented dan non profit oriented yang dihasilkan selama satu periode waktu Sedangkan menurut armstrong dan baron (dalam Fahmi 2014:226) mengatakan kinerja merupakan hasil pekerjaan yang mempunyai hubungan kuat dengan tujuan strategis organisasi, kepuasan konsumen dan memberikan kontibusi ekonom Sedangkan menurut Indra Bastian (dalam Fahmi, 2014 : 226) menyatakan bahwa kinerja adalah gambaran mengenai tingkat pencapaian pelaksanaan suatu kegiatan/program/kebijaksanaan dalam mewujudkan sasaran, tujuan, misi, dan visi organisasi yang tertuang dalam perumusan skema strategis (strategic planning) suatu organisasi. Menurut erni dan donni (2018:121) "kinerja merupakan tingkat keberhasilan pegawai dalam menyelesaikan pekerjaannya. Menurut Mathis dan Jackson (dalam erni dan donni 2018:122) kinerja adalah apa yang dilakukan atau tidak dilakukan oleh pegawai dalam mengemban pekerjaannya.

\subsection{Kepemimpinan}

Menurut Fahmi (2014:58) pengertian Kepemimpinan sebagai berikut Kepemimpinan merupakan suatu ilmu yang mengkaji secara komprehensif tentang bagaimana mengarahkan, mempengaruhi, dan mengawasi orang lain untuk mengerjakan tugas sesuai dengan perintah yang direncanakan. Menurut Stephen P. Robbins (dalam Fahmi, 2014:58) pengertian kepemimpinan sebagai berikut Kepemimpinan adalah kemampuan untuk mempengaruhi suatu kelompok ke arah tercapainya tujuan. Selanjutnya menurut Richard L. Daft (dalam Fahmi, 2014 : 58), pengertian kepemimpinan sebagai berikut. Kepemimpinan (leadership) adalah kemampuan mempengaruhi orang yang mengarah kepada pencapaian tujuan. Pendapat yang sama dikemukakan oleh G. R. Terry (dalam Fahmi, 2014 : 58) memberikan definisi. Leadership is the activity of influencing people to strive willing for mutul objectives. Kepemimpinan dalam suatu birokrasi sangat penting, oleh karena pemimpinlah yang dapat membuat keputusan, memotivasi bawahan 
melaksanakan keputusan yang telah dibuat, dan pemimpinlah juga yang mengawasi pelaksanaan keputusan tersebut agar dapat tercapai tujuan. Kemudian Ricky W Griffin (dalam Fahmi, 2014:58) mengatakan pengertian kepemimpinan sebagai berikut, pemimpin adalah individu yang mampu memperngaruhi perilaku orang lain tanpa harus mengandalkan kekerasan; pemimpinan adalah individu yang di terima oleh orang lain sebagai pemimpin. Kepemimpinan seseorang sangat besar perannya dalam setiap pengambilan keputusan, sehingga membuat keputusan dan mengambil tanggung jawab terhadap hasilnya adalah salah satu tugas seorang pemimpin. Menurut Rivai, (dalamKhotimah, 2015:7) pengertian kepemimpinan sebagai berikut.Kepemimpinan adalah meliputi proses dalam menentukan tujuan organisasi, memotivasi perilaku pengikut untuk mencapai tujuan, memengaruhi untuk memperbaiki kelompok dan budayanya. Menurut Wibowo (2014:265) Pengertian Kepemimpinan sebagai berikut. Kepemimpinan pada hakikatnya adalah kemampuan individu dengan menggunakan kekuasaannya melakukan proses memengaruhi, memotivasi, dan mendukung usaha yang memungkinkan orang lain memberikan kontribusi pada pencapaian tujuan organisasi

\subsection{Motivasi}

Menurut Afandi (2018:23), motivasi kerja adalah keinginan yang timbul dari dalam diri seseorang atau individu karena terinspirasi, tersemangati dan terdorong untuk melakukan aktifitas dengan keihklasan, senang hati dan sungguhsungguh sehingga hasil dari aktifitas yang dia lakukan mendapat hasil yang baik dan berkualitas. Menurut Fahmi (2014:143), bahwa motivasi adalah aktivitas perilaku yang bekerja dalam usaha memenuhi kebutuhan-kebutuhan yang diinginkan".Sedangkan "Menurut Wibowo
(2017:322) Motivasi adalah dorongan untuk bertindak terhadap serangkaian proses perilaku manusia dengan mempertimbangkan arah, intensitas dan ketekunan pada pencapaian tujuan.Menurut Stefan Ivanko (dalam Hamali, 2018:131) Motivasi keinginan dan energi seseorang yang diarahkan untuk pencapaian tujuan. Sedangkan menurut Kondalka (dalam Hamali, 2018:131) Motivasi adalah harapan dalam yang membakat yang disebabkan oleh kebutuhan, keinginan dan kemauan yang mendorong seseorang individu untuk menggunakan energi fisik dan mentalnya demi tercapainya tujuan-tujuan yang diinginkan

\subsection{Kompensasi}

Menurut Sutrisno (2016:183) kompensasi adalah segala sesuatu yang diterima oleh karyawan sebagai balas jasa untuk kerja mereka. Menurut Hasibuan (2014:118) kompensasi adalah pendapatan yang berbentuk uang, barang langsung atau tidak langsung yang diterima karyawan sebagai imbalan atas jasa yang diberikan kepada perusahaan. Menurut Hamali (2016:78) "kompensasi merupakan salah satu fungsi yang penting dalam manajemen SDM. Kompensasi merupakan segala sesuatu yang diterima oleh karyawan dari perusahaan sebagai balas jasa untuk kerja mereka dalam bentuk pemberian uang, pemberial material (barang), fasilitasfasilitas, dan dalam bentuk kesempatan berkarier, Singodimejo dalam Edy Sutrisno, (2015:183).Menurut Mangkunegara (2017:83) Pengertian, kompensasi sesuatu yang dipertimbangkan sebagai suatu yang sebanding.Dalam kepegawaian, hadiah yang bersifat uang merupakan kompensasi yang diberikan kepada pegawai sebagai penghargaan dari pelayanan mereka.

\subsection{Hipotesis}

1. Diduga Kepemimpinan, Motivasidan Kompensasi berpengaruh signifikan 
secara simultan terhadap Kinerja Pegawai di Badan Pengelola Pajak dan Retribusi Daerah Kota Lubuklinggau.

2. Diduga Kepemimpinan, dan Motivasi berpengaruh signifikan secara simultan terhadap Kinerja Pegawai di Badan Pengelola Pajak dan Retribusi Daerah Kota Lubuklinggau.

3. Diduga Kepemimpinan, dan Kompensasi berpengaruh signifikan secara simultan terhadap Kinerja Pegawai di Badan Pengelola Pajak dan Retribusi Daerah Kota Lubuklinggau.

4. Diduga Motivasidan Kompensasi berpengaruh signifikan secara simultan terhadap Kinerja Pegawai di Badan Pengelola Pajak dan Retribusi Daerah Kota Lubuklinggau.

5. Diduga Kepemimpinan, berpengaruh signifikan secara parsial terhadap Kinerja Pegawai di Badan Pengelola Pajak dan Retribusi Daerah Kota Lubuklinggau.

6. Diduga Motivasi, berpengaruh signifikan secara parsial terhadap Kinerja Pegawai di Badan Pengelola Pajak dan Retribusi Daerah Kota Lubuklinggau.

7. Diduga Kompensasi, berpengaruh signifikan secara parsial terhadap Kinerja Pegawai di Badan Pengelola Pajak dan Retribusi Daerah Kota Lubuklinggau.

\section{METODOLOGI PENELITIAN}

Berdasarkan permasalahan yang dieliti pendekatan dalam penelitian ini adalah pendekatan kuantitatif dengan melakukan pengujian hipotesis. Penelitian kuantitatif merupakan metode yang berlandaskan pada filsafat positivisme yang digunakan untuk meneliti populasi atau sampel tertentu (Sugiono,2011). Sekaran dan Bouqie (2016) menjelaskan pendekatan kuantitatif sebagai penelitian menggunakan data-data berbentuk angka yang diolah dan dianalisis secara matematika atau statistic.

\subsection{Desain Penelitian}

Desain penelitian digunakan sebagai dasar strategi penelitian agar Peneliti dapat memeroleh data penelitian yang sesuai dengan tujuan penelitian. Desain yang digunakan dalam penelitian ini merupakan penelitian asosiatif yaitu penelitian yang berusaha mencari hubunganpengaruh antara satu variabel dengan variabel lain yang terdiri dari variabel independen (Kepemimpinan, Motivasi dan Kompensasi) dengan variable dependen (Kinerja Pegawai).

\subsection{Variabel Penelitian}

Variabel yang digunakan dalam penelitian ini adalah : Variabel bebas (independent variabel) adalah Kepemimpinan $\left(\mathrm{X}_{1}\right)$, Motivasi $\left(\mathrm{X}_{2}\right)$ dan Kompensasi $\left(\mathrm{X}_{3}\right)$. Variabel terikat (dependent variabel) adalah Kinerja Pegawai (Y).

\subsection{Populasi}

Populasi adalah wilayah Generalisasi yang terdiri atas; obyek/subyek yang mempunyai kuantitas dan karateristik tertentu yang ditetapkan oleh peneliti untuk dipelajari dan kemudian ditarik kesimpulannya, Sugiyono, (2013:148) Populasi dalam penelitian ini berjumlah 38 orang pegawai di Badan Pengelola Pajak Dan Retribusi Daerah Kota Lubuklinggau.

\subsection{Sampel}

Menurut Sugiyono (2013:150) sampling Jenuh adalah teknik penentuan sampel bila semua anggota populasi digunakan sebagai sampel. Jadi sampel yang digunakan dalam penelitian berjumlah 38 orang pegawai, maka tehnik penentuan sampel yang digunakan adalah sampel jenuh atau sampel sensus dimana semua anggota populasi dijadikan sampel. 


\subsection{Sumber Data}

Menurut Syofian (2017:37), sumber data penelitian ada dua, antara lain sebagai berikut Data primer adalah data yang dikumpulkan sendiri oleh Peneliti, langsung dari sumber pertama atau tempat objek penelitian dilakukan, dan Data sekunder adalah data yang diterbitkan atau digunakan oleh organisasi yang bukan pengelolanya. Dalam penelitian ini data yang diperoleh bersumber dari data primer (pengumpulan data kuisioner) dan data sekunder (referensi buku/ jurnal/artikel/ dan lain sebagainya).

\subsection{Teknik Pengumpulan Data}

Menurut Syofian (2017:34), teknik pengumpulan data di antaranyasebagai berikut 1. Observasi, adalah kegiatan pengumpulan data dengan melakukan penelitian langsung terhadap kondisi lingkungan objek penelitian yang mendukung kegiatan penelitian, sehingga didapat gambaran secara jelas tentang kondisi objek penelitian tersebut. 2 . Dokumentasi, yaitu pengumpulan data mengenai hal-hal atau variabel yang berupa catatan, transkip, buku, surat kabar, majalah, prasasti, notulen rapat, agenda dan sebagainya. Teknik pengumpulan ini digunakan dalam rangka mendukung teori dan data yang diperoleh baik melalui observasi maupun kuisioner.3. Kuisioner, merupakan teknik pengumpulan data dengan cara membagikan kuisioner kepada pihakpihak yang bersangkutan dalam penelitian. Dalam penelitian ini teknik-teknik pengumpulan data yang digunakan oleh peneliti untuk memeroleh dan mengumpulkan data melalui observasi, dokumentasi, dan angket kuisioner.

\section{HASIL DAN PEMBAHASAN}

\subsection{Hasil Penelitian}

\section{Uji t (Kepemimpinan)}

Untuk melihat pengaruh parsial dari masing-masing variabel bebas yaitu Kepemimpinan terhadap variabel terikat yaitu kinerja pegawai dapat dijelaskan dengan menggunakan uji t. Hasil uji t secara rinci disajikan pada tabel dibawah ini :

Tabel 1

Hasil Uji Parsial

\begin{tabular}{|l|c|c|}
\hline Variabel (X1) & t & Sig. \\
\hline Kepemimpinan & 4,750 &, 000 \\
\hline
\end{tabular}

Sumber : Hasil Olah Data Tahun 2020

Berdasarkan tabel 1 hasil uji t di atas dapat dijelaskan sebagai berikut : bahwa variabel Kepemimpinan (X1) terhadap kinerja pegawai di Badan Pengelola Pajak Dan Retribusi Daerah Di Kota Lubuklinggau menunjukan nilai $t_{\text {hitung }}=4,750$ lebih besar dari nilai $\mathrm{t}_{\text {tabel }} 1.687$ dengan tingkat signifikan $=0,000<(\alpha) 0.05$, df (n-1) $38-1=37$ adalah sebesar 1.687 hal ini menunjukan Ho ditolak dan Ha diterima dan secara parsial variabel Kepemimpinan memiliki pengaruh yang signifikan terhadap Kinerja Pegawai di Badan Pengelola Pajak Dan Retribusi Daerah Di Kota Lubuklinggau.

\section{Uji t (Motivasi)}

Untuk melihat pengaruh parsial dari masing-masing variabel bebas yaitu Motivasi terhadap variabel terikat yaitu kinerja pegawai dapat dijelaskan dengan menggunakan uji t. Hasil uji t secara rinci disajikan pada tabel dibawah ini:

Tabel 2

Hasil Uji t (Parsial)

\begin{tabular}{|l|c|c|}
\hline Variabel (X1) & t & Sig \\
\hline Motivasi & 4,110 &, 000 \\
& & \\
\hline
\end{tabular}

Berdasarkan tabel 3 hasil uji $\mathrm{t}$ di atas dapat dijelaskan sebagai berikutbahwa variabel Kompensasi $\left(\mathrm{X}_{3}\right)$ terhadap kinerja pegawai menunjukan nilai thitung $=5,222$ lebih besar dari nilai ttabel1.687dengan tingkat signifikan $=0,000<(\alpha) 0.05, \mathrm{df}(\mathrm{n}-1) 38-1$ 
$=37$ adalah sebesar 1.687 hal ini menunjukan Ho ditolak dan Ha diterima dan secara parsial variabel Kompensasi memiliki pengaruh yang signifikan terhadap Kinerja Pegawai di Badan Pengelola Pajak Dan Retribusi.

\section{Uji Simultan (Uji F)}

a. Kepemimpinan, Motivasi dan Kompensasi terhadap variabel terikat kinerja Pegawai

Hasil uji F (simultan) variabel Kepemimpinan, Motivasi dan Kompensasiterhadap variabel terikat kinerja PegawaiBadan Pengelola Pajak Dan Retribusi Daerah Di Kota Lubuklinggau dapat dilihat di Tabel 4 di bawah :

\section{Tabel 4}

Pengujian Terhadap Hipotesis

ANOVA $^{a}$

\begin{tabular}{|c|r|r|r|r|r|}
\hline Model & \multicolumn{1}{|c|}{$\begin{array}{c}\text { Sum of } \\
\text { Squares }\end{array}$} & df & $\begin{array}{c}\text { Mean } \\
\text { Square }\end{array}$ & $F$ & Sig. \\
\hline Regression & 622,267 & 3 & 207,422 & 18,779 &, $000^{\mathrm{b}}$ \\
1 Residual & 375,549 & 34 & 11,046 & & \\
Total & 997,816 & 37 & & & \\
\hline
\end{tabular}

Sumber : Hasil Olah Data Tahun 2020.

Berdasarkan tabel 4. pengujian dengan SPSS 20 dapat dilihat bahwa $F_{\text {hitung }}$ yang diperoleh adalah 18,779>Ftabel = 2.88dan tingkat kemaknaan secara simultan signifikansinya adalah $0,000<(\alpha)=0,05 \mathrm{df}$ $=\mathrm{n}-\mathrm{k}=38-3-1=34$ adalah sebesar 2.88sehingga Ho ditolak dan Ha diterima. artinya menunjukan bahwa secara bersamasama (simultan) variabel bebas yaitu Kepemimpinan, Motivasi dan Kompensasi memiliki pengaruh yang signifikan terhadap variabel terikat yaitu Kinerja pegawai, jadi terbukti kebenarannya dan hipotesisnya dapat diterima. b. Kepemimpinan dan Motivasi terhadap variabel terikat kinerja Pegawai

Hasil uji F (simultan) variabel Kepemimpina dan Motivasi terhadap variabel terikat kinerja Pegawai Badan Pengelola Pajak Dan Retribusi Daerah Di Kota Lubuklinggau dapat dilihat di Tabel 5 di bawah:

Tabel 5

Pengujian Terhadap Hipotesis

\begin{tabular}{|c|c|c|c|c|c|c|}
\hline \multicolumn{2}{|c|}{ Model } & $\begin{array}{c}\text { Sum of } \\
\text { Squares }\end{array}$ & df & Mean & $\mathrm{F}$ & Sig. \\
\hline \multirow{3}{*}{1} & Regression & 538,281 & 2 & 269,140 & 20,499 &, $000^{b}$ \\
\hline & Residual & 459,535 & 35 & 13,130 & & \\
\hline & Total & 997,816 & 37 & & & \\
\hline
\end{tabular}

Berdasarkan tabel 5 pengujian dengan SPSS 20 dapat dilihat bahwa $F_{\text {hitung }}$ yang diperoleh adalah 20,499>Ftabel = 3.27dan tingkat kemaknaan secara simultan signifikansinya adalah $0,000<(\alpha)=0,05 \mathrm{df}$ $=\mathrm{n}-\mathrm{k}=38-2-1=35$ adalah sebesar 3.27sehingga Ho ditolak dan Ha diterima. artinya menunjukan bahwa secara bersamasama (simultan) variabel bebas yaitu Kepemimpinan, dan Motivasi memiliki pengaruh yang signifikan terhadap variabel terikat yaitu Kinerja pegawai, jadi terbukti kebenarannya dan hipotesisnya dapat diterima.

\section{c. Kepemimpinan dan Kompensasi terhadap variabel terikat kinerja Pegawai}

Hasil uji F (simultan) variabel Kepemimpinan dan Kompensasi terhadap variabel terikat kinerja Pegawai Badan Pengelola Pajak Dan Retribusi Daerah Di Kota Lubuklinggaudapat dilihat di Tabel 5 di bawah: 
Tabel 6

\section{Pengujian Terhadap Hipotesis}

\begin{tabular}{|c|r|r|c|c|c|}
\hline \multicolumn{7}{|c|}{ ANOVA $^{\mathrm{a}}$} \\
& $\begin{array}{c}\text { Sum of } \\
\text { Squares }\end{array}$ & $\mathrm{df}$ & Mean & $\mathrm{F}$ & Sig. \\
& Square & & \\
\hline Regression & 521,717 & 2 & 260,858 & 19,177 & \multirow{2}{*}{$000^{\mathrm{b}}$} \\
1 Residual & 476,099 & 35 & 13,603 & & \\
Total & 997,816 & 37 & & & \\
\hline
\end{tabular}

Sumber : Hasil Olah Data Tahun 2020.

Berdasarkan tabel 6. pengujian dengan SPSS 20 dapat dilihat bahwa $F_{\text {hitung }}$ yang diperoleh adalah 19,177>Ftabel = 3.27dan tingkat kemaknaan secara simultan signifikansinya adalah $0,000<(\alpha)=0,05 \mathrm{df}$ $=\mathrm{n}-\mathrm{k}=38-2-1=35$ adalah sebesar 3.27sehingga Ho ditolak dan Ha diterima. artinya menunjukan bahwa secara bersamasama (simultan) variabel bebas yaitu Kepemimpinan dan Kompensasi memiliki pengaruh yang signifikan terhadap variabel terikat yaitu Kinerja pegawai, jadi terbukti kebenarannya dan hipotesisnya dapat diterima.

\section{Motivasi dan Kompensasi terhadap variabel terikat kinerja Pegawai}

Hasil uji F (simultan) variabel Motivasi dan Kompensasi terhadap variabel terikat kinerja PegawaiBadan Pengelola Pajak Dan Retribusi Daerah Di Kota Lubuklinggaudapat dilihat di Tabel 7 di bawah :

Tabel 7

Pengujian Terhadap Hipotesis

\begin{tabular}{|l|c|c|c|c|c|}
\hline Model & $\begin{array}{c}\text { Sum of } \\
\text { Squares }\end{array}$ & $d f$ & $\begin{array}{c}\text { Mean } \\
\text { Square }\end{array}$ & $F$ & Sig. \\
\hline Regression & 557,660 & 2 & 278,830 & 22,172 &, $000^{\mathrm{b}}$ \\
1 Residual & 440,156 & 35 & 12,576 & & \\
Total & 997,816 & 37 & & & \\
\hline
\end{tabular}

Sumber : Hasil Olah Data Tahun 2020.

Berdasarkan tabel 7 pengujian dengan SPSS 20 dapat dilihat bahwa $F_{\text {hitung }}$ yang diperoleh adalah 22,172 >Ftabel = 3.27dan tingkat kemaknaan secara simultan signifikansinya adalah $0,000<(\alpha)=0,05 \mathrm{df}$ $=\mathrm{n}-\mathrm{k}=38-2-1=35$ adalah sebesar 3.27sehingga Ho ditolak dan Ha diterima. artinya menunjukan bahwa secara bersamasama (simultan) variabel bebas yaitu Motivasi dan Kompensasi memiliki pengaruh yang signifikan terhadap variabel terikat yaitu Kinerja pegawai, jadi terbukti kebenarannya dan hipotesisnya dapat diterima.

\subsection{Pembahasan}

\section{Pengaruh Kepemimpinan, Motivasi dan Kompensasi Terhadap Kinerja Pegawai Badan}

Dari hasil uji regresi linear berganda untuk variabel Kepemimpinan, Motivasi dan Kompensasi Terhadap Kinerja Pegawai Badan Pengelola Pajak Dan Retribusi Daerah Di Kota Lubuklinggau, diperoleh persamaan regresi $\mathrm{Y}=\mathrm{a}+\mathrm{b} 1 \mathrm{X} 1+\mathrm{b} 2 \mathrm{X} 2+\mathrm{b} 3 \mathrm{X} 3$. Kinerja Pegawai $=31,175$ (Constant) + 0,317 (Kepemimpinan) $+0,400$ (Motivasi) + 0,420 (Kompensasi) Dari persamaan regresi di atas, dapat dijelaskan Nilai konstanta yaitu sebesar 31,175 Hal ini menunjukkan bahwa apabila variabel Kepemimpinan, Motivasi dan Kompensasi tidak mengalami perubahan atau nilainya nol, maka nilai dari variabel kinerja Pegawai adalah sebesar 31,175. Nilai koefisien regresi variabel Kepemimpinan sebesar 0,317 satuan. Hal ini menunjukkan bahwa apabila nilai variabel Kepemimpinan meningkat sebesar satu satuan, maka nilai variabel Kepemimpinan akan mengalami perubahan secara positif sebesar 0,317 satuan. Sebaliknya jika nilai regresi 0,317 turun sebesar satu satuan, maka kinerja pegawai juga diprediksikan mengalami penurunan sebesar 0,317 satuan. Oleh karena itu dapat disimpulkan Kepemimpinan mempunyai hubungan yang searah terhadap Kinerja Pegawai. Nilai koefisien regresi variabel Motivasi sebesar 0,400 satuan, hal ini menunjukkan bahwa apabila nilai 
variabel Motivasi meningkat sebesar satu satuan, maka nilai variabel Motivasiakan mengalami perubahan secara positif sebesar 0,400 satuan. Sebaliknya jika nilai regresi 0,400 turun sebesar satu satuan, maka kinerja juga diprediksikan mengalami penurunan sebesar 0,400 satuan. Oleh karena itu dapat disimpulkan Motivasi mempunyai hubungan yang searah terhadap kinerja Pegawai.Nilai koefisien regresi variabel Kompensasi sebesar 0,420 satuan, hal ini menunjukkan bahwa apabila nilai variabel Kompensasi meningkat sebesar satu satuan, maka nilai variabel Kompensasi akan mengalami perubahan secara positif sebesar 0,420 satuan. Sebaliknya jika nilai regresi 0,420 turun sebesar satu satuan, maka kinerja juga diprediksikan mengalami penurunan sebesar 0,420 satuan. Oleh karena itu dapat disimpulkan Kompensasi mempunyai hubungan yang searah terhadap kinerja Pegawai.

Simpulannya, Kepemimpinan, Motivasi dan Kompensasi Terhadap Kinerja Pegawai Badan Pengelola Pajak Dan Retribusi Daerah Di Kota Lubuklinggaumerupakan hal yang penting dalam meningkatan kinerja pegawai. Oleh karena itu, jika ingin Badan Pengelola Pajak Dan Retribusi Daerah Di Kota Lubuklinggau ingin selalu meningkatkan kinerja pegawainya secara optimal. Salah satu caranya,Pimpinan selalu memberikan arahan kepada pegawai agar dapat meningkatkan kinerjanya dengan cara memberikan motivasi dan memperhatikan kompensasi yang dibutuhkan pegawai sehingga pegawai terdorong untuk bekerja dengan optimal untuk kemajuan organisasi Badan Pengelola Pajak Dan Retribusi Daerah Di Kota Lubuklinggau.

\section{Kepemimpinan dan Motivasi terhadap kinerja Pegawai di Badan Pengelola Pajak Dan Retribusi Daerah Di Kota Lubuklinggau.}

Dari hasil uji regresi linear berganda untuk variabel Kepemimpinan, dan Motivasi
Terhadap Kinerja Pegawai Badan Pengelola Pajak Dan Retribusi Daerah Di Kota Lubuklinggau, diperoleh persamaan regresi $\mathrm{Y}=\mathrm{a}+\mathrm{b} 1 \mathrm{X} 1+\mathrm{b} 2 \mathrm{X} 2$. Kinerja Pegawai $=$ 36,494 (Constant) + 0,503 (Kepemimpinan $)+$ 0,482 (Motivasi) Dari persamaan regresi di atas, dapat dijelaskan Nilai konstanta yaitu sebesar 36,494 Hal ini menunjukkan bahwa apabila variabel Kepemimpinan, dan Motivasi tidak mengalami perubahan atau nilainya nol, maka nilai dari variabel kinerja Pegawai adalah sebesar 36,494.Nilai koefisien regresi variabel Kepemimpinan sebesar 0,503 satuan. Hal ini menunjukkan bahwa apabila nilai variabel Kepemimpinan meningkat sebesar satu satuan, maka nilai variabel Kepemimpinan akan mengalami perubahan secara positif sebesar 0,503 satuan. Sebaliknya jika nilai regresi 0,503turun sebesar satu satuan, maka kinerja pegawai juga diprediksikan mengalami penurunan sebesar 0,503satuan. Oleh karena itu dapat disimpulkan Kepemimpinan mempunyai hubungan yang searah terhadap Kinerja Pegawai.Nilai koefisien regresi variabel Motivasi sebesar 0,482satuan, hal ini menunjukkan bahwa apabila nilai variabel Motivasi meningkat sebesar satu satuan, maka nilai variabel Motivasi akan mengalami perubahan secara positif sebesar 0,482 satuan. Sebaliknya jika nilai regresi 0,482turun sebesar satu satuan, maka kinerja juga diprediksikan mengalami penurunan sebesar 0,482satuan. Oleh karena itu dapat disimpulkan Motivasi mempunyai hubungan yang searah terhadap kinerja Pegawai. Simpulannya, Kepemimpinan dan Motivasi Terhadap Kinerja Pegawai Badan Pengelola Pajak Dan Retribusi Daerah Di Kota Lubuklinggaumerupakan hal yang penting dalam meningkatan kinerja pegawai. Oleh karena itu, jika ingin Badan Pengelola Pajak Dan Retribusi Daerah Di Kota Lubuklinggau ingin selalu meningkatkan kinerja pegawainya secara optimal. Salah satu caranya,Pimpinan selalu memberikan motivasi kepada pegawainya sehingga 
pegawai dapat bersemangat bekerja dan dapat meningkatkan apa yang menjadi tujuan dari Badan Pengelola Pajak Dan Retribusi Daerah Di Kota Lubuklinggau.

\section{Kepemimpinan dan Kompensasi terhadap kinerja Pegawai di Badan Pengelola Pajak Dan Retribusi Daerah Di Kota Lubuklinggau.}

Dari hasil uji regresi linear berganda untuk variabel Kepemimpinan, dan Motivasi Terhadap Kinerja Pegawai Badan Pengelola Pajak Dan Retribusi Daerah Di Kota Lubuklinggau, diperoleh persamaan regresi $\mathrm{Y}=\mathrm{a}+\mathrm{b} 1 \mathrm{X} 1+\mathrm{b} 3 \mathrm{X} 3$. Kinerja Pegawai $=$ 39,029 (Constant) + 0,374 (Kepemimpinan)+ 0,524 (Kompensasi). Dari persamaan regresi di atas, dapat dijelaskan Nilai konstanta yaitu sebesar 39,029Hal ini menunjukkan bahwa apabila variabel Kepemimpinan dan Kompensasitidak mengalami perubahan atau nilainya nol, maka nilai dari variabel kinerja Pegawai adalah sebesar 39,029. Nilai koefisien regresi variabel Kepemimpinan sebesar 0,374satuan. Hal ini menunjukkan bahwa apabila nilai variabel Kepemimpinan meningkat sebesar satu satuan, maka nilai variabel Kepemimpinan akan mengalami perubahan secara positif sebesar 0,374 satuan. Sebaliknya jika nilai regresi 0,374 turun sebesar satu satuan, maka kinerja pegawai juga diprediksikan mengalami penurunan sebesar 0,374satuan. Oleh karena itu dapat disimpulkan Kepemimpinan mempunyai hubungan yang searah terhadap Kinerja Pegawai.Nilai koefisien regresi variabel Kompensasi sebesar 0,524 satuan, hal ini menunjukkan bahwa apabila nilai variabel Kompensasi meningkat sebesar satu satuan, maka nilai variabel Kompensasi akan mengalami perubahan secara positif sebesar 0,524 satuan. Sebaliknya jika nilai regresi 0,524 turun sebesar satu satuan, maka kinerja juga diprediksikan mengalami penurunan sebesar 0,524 satuan. Oleh karena itu dapat disimpulkan Kompensasi mempunyai hubungan yang searah terhadap kinerja
Pegawai. Simpulannya, Kepemimpinan, Kompensasi Terhadap Kinerja Pegawai Badan Pengelola Pajak Dan Retribusi Daerah Di Kota Lubuklinggaumerupakan hal yang penting juga dalam meningkatan kinerja pegawai. Oleh karena itu, jika ingin Badan Pengelola Pajak Dan Retribusi Daerah Di Kota Lubuklinggau ingin selalu meningkatkan kinerja pegawainya secara optimal. Salah satu caranya,Pimpinan harus memperhatikan kebutuhan/kompensasi apa saja yang dibutuhkan pegawai sehingga pegawai dapat bekerja secara optimal karena kebutuhan seharinya terpenuhi dan dapat mencapai visi dan misi Badan Pengelola Pajak Dan Retribusi Daerah Di Kota Lubuklinggau.

\section{Pengaruh Motivasi dan Kompensasi terhadap kinerja Pegawai di Badan Pengelola Pajak Dan Retribusi Daerah Di Kota Lubuklinggau.}

Dari hasil uji regresi linear berganda untuk variabel Motivasi dan Kompensasi Terhadap Kinerja Pegawai Badan Pengelola Pajak Dan Retribusi Daerah Di Kota Lubuklinggau, diperoleh persamaan regresi $\mathrm{Y}=\mathrm{a}+\mathrm{b} 2 \mathrm{X} 2+\mathrm{b} 3 \mathrm{X} 3$. bKinerja Pegawai $=$ 39,571 (Constant) + 0,445 (Motivasi) + 0,609 (Kompensasi). Dari persamaan regresi di atas, dapat dijelaskan Nilai konstanta yaitu sebesar 39,571Hal ini menunjukkan bahwa apabila variabel Motivasi dan Kompensasi tidak mengalami perubahan atau nilainya nol, maka nilai dari variabel kinerja Pegawai adalah sebesar 39,571. Nilai koefisien regresi variabel Motivasi sebesar 0,445satuan, hal ini menunjukkan bahwa apabila nilai variabel Motivasi meningkat sebesar satu satuan, maka nilai variabel Motivasi akan mengalami perubahan secara positif sebesar 0,445 satuan. Sebaliknya jika nilai regresi 0,445 turun sebesar satu satuan, maka kinerja juga diprediksikan mengalami penurunan sebesar 0,445 satuan. Oleh karena itu dapat disimpulkan Motivasi mempunyai hubungan yang searah terhadap kinerja 
Pegawai. Nilai koefisien regresi variabel Motivasi sebesar 0,609 satuan, hal ini menunjukkan bahwa apabila nilai variabel Motiva simeningkat sebesar satu satuan, maka nilai variabel Motivasi akan mengalami perubahan secara positif sebesar 0,609 satuan. Sebaliknya jika nilai regresi 0,609 turun sebesar satu satuan, maka kinerja juga diprediksikan mengalami penurunan sebesar 0,609satuan. Oleh karena itu dapat disimpulkan Motivasi mempunyai hubungan yang searah terhadap kinerja Pegawai. Simpulannya, Motivasi dan Kompensasi merupakan dua hal yang harus selalu diperhatikan oleh organisasi. Oleh karena itu, Badan Pengelola Pajak Dan Retribusi Daerah Di Kota Lubuklinggau atau pimpinan organisasi harus selalu memperhatikan dan menjaga kebutuhan pegawai sehingga pegawai selalu meningkatkan kinerjanya untuk kemajuan Badan Pengelola Pajak Dan Retribusi Daerah Di Kota Lubuklinggau

\section{Kepemimpinan terhadap Kinerja Pegawai}

Hasil penelitian menunjukkan, dari uji regresi linear sederhana terhadap variabel Kepemimpinan terhadap kinerja Pegawai di Badan Pengelola Pajak Dan Retribusi Daerah Di Kota Lubuklinggau diperoleh persamaan regresi $\mathrm{Y}=\mathrm{a}+\mathrm{bX}$. Kinerja Pegawai $=$ 48,128 (Constant) + 0,633 (Kepemimpinan). Dari persamaan regresi di atas, dapat dijelaskankan Nilai konstanta yaitu sebesar 48,128Hal ini menunjukan bahwa apabila variabel Kepemimpinan tidak ada atau nilainya nol, maka nilai dari kinerja pegawai adalah sebesar 48,128. Nilai koefisien regresi variabel Kepemimpinan sebesar 0,633 satuan, hal ini menunjukan bahwa apabila nilai Kepemimpinan meningkat sebesar satu satuan, maka nilai variabel kepemimpinan akan mengalami perubahan secara positif sebesar 0,633 satuan. Sebaliknya jika nilai regresi kepemimpinan turun sebesar satu satuan, maka kinerja pegawai juga diprediksikan mengalami penurunan sebesar
0,633 satuan. Oleh karena itu dapat disimpulkan bahwa kepemimpinan mempunyai hubungan yang searah terhadap Kinerja pegawai. Hubungan erat di antara Kepemimpinan dengan kinerja pegawai dalam penelitian ini dapat dibuktikan melalui Kepemimpinan $\left(\mathrm{X}_{1}\right)$ yang diperoleh adalah 0,621. Hal ini dapat diartikan bahwa, hubungan antara variabel bebas Kepemimpinan $\left(\mathrm{X}_{1}\right)$ dan variabel terikat Kinerja (Y) secara parsial dapat dikatakan kuat yaitu sebesar 0,621 karena nilai $r$ berada di interval koefisien 0,60 - 0,799. Hasil uji hipotesis kelima variabel Kepemimpinan (X1) terhadap kinerja pegawai di Badan Pengelola Pajak Dan Retribusi Daerah Di Kota Lubuklinggau menunjukan nilai $\mathrm{t}_{\text {hitung }}$ $=4,750$ lebih besar dari nilai $t_{\text {tabel }} 1.687$ dengan tingkat signifikan $=0,000<(\alpha) 0.05$, df (n-1) $38-1=37$ adalah sebesar 1.687 hal ini menunjukan Ho ditolak dan Ha diterima dan secara parsial variabel Kepemimpinan memiliki pengaruh yang signifikan terhadap Kinerja Pegawai di Badan Pengelola Pajak Dan Retribusi Daerah Di Kota Lubuklinggau. Hasil uji $\mathrm{t}$ ini membuktikan bahwa, hipotesis kelima penelitian ini yaitu "Ada pengaruh signifikan dari Kepemimpinan secara parsial terhadap kinerja pegawai Badan Pengelola Pajak Dan Retribusi Daerah Di Kota Lubuklinggauterbukti kebenarannya dan hipotesis diterima.

\section{Pengaruh Motivasi terhadap Kinerja Pegawai}

Hasil penelitian menunjukkan, dari uji regresi linear sederhana terhadap variabel Motivasi terhadap kinerja Pegawai di Badan Pengelola Pajak Dan Retribusi Daerah Di Kota Lubuklinggau diperoleh persamaan regresi $\mathrm{Y}=\mathrm{a}+\mathrm{bX2}$. Kinerja pegawai $=$ 59,644(Constant) + 0,659(Motivasi). Dari persamaan regresi di atas, dapat dijelaskankan. Nilai konstanta yaitu sebesar 59,644 . Hal ini menunjukan bahwa apabila variabel Motivasi tidak ada atau nilainya nol, 
maka nilai dari kinerja pegawai adalah sebesar 59,644. Nilai koefisien regresi variabel Motivasi sebesar 0,659satuan, hal ini menunjukan bahwa apabila nilai variabel Motivasi meningkat sebesar satu satuan, maka nilai variabel Motivasi akan mengalami perubahan secara positif sebesar 0,659 satuan. Sebaliknya jika nilai regresi Motivasi turun sebesar satu satuan, maka kinerja pegawai juga diprediksikan mengalami penurunan sebesar 0,659 satuan. Oleh karena itu dapat disimpulkan bahwa Motivasi mempunyai hubungan yang searah terhadap kinerja pegawai.Hubungan erat di antara Motivasi dengan kinerja pegawai dalam penelitian ini dapat dibuktikan melalui hasil uji koefisien korelasi (r) variabel bebas Motivasi $\left(\mathrm{X}_{2}\right)$ yang diperoleh adalah 0,565 Hal ini dapat diartikan bahwa hubungan antara variabel bebas Motivasi $\left(\mathrm{X}_{2}\right)$ dan variabel terikat Kinerja (Y) secara parsial dapat dikatakan Cukup yaitu sebesar 0,565 karena nilai $\mathrm{r}$ berada di interval koefisien 0,40 - 0,599. Hasil uji hipotesis keenam variabel Motivasi $\left(\mathrm{X}_{2}\right)$ terhadap kinerja pegawai menunjukan nilai $t_{\text {hitung }}=4,110$ lebih besar dari nilai $\mathrm{t}_{\text {tabel }} 1.687$ dengan tingkat signifikan $=0,000<(\alpha) 0.05, \mathrm{df}(\mathrm{n}-1)$ $38-1=37$ adalah sebesar 1.687, hal ini menunjukan Ho ditolak dan Ha diterima dan secara parsial variabel Motivasi memiliki pengaruh yang signifikan terhadap Kinerja Pegawai Di Badan Pengelola Pajak Dan Retribusi Daerah Di Kota Lubuklinggau. Hasil uji $t$ ini membuktikan bahwa, hipotesis keenam penelitian ini yaitu "Ada pengaruh signifikan dari Motivasi secara parsial terhadap kinerja pegawai Badan Pengelola Pajak Dan Retribusi Daerah Di Kota Lubuklinggauterbukti kebenarannya dan hipotesis diterima.

\section{Pengaruh Kompensasi terhadap Kinerja Pegawai}

Hasil penelitian menunjukkan, dari uji regresi linear sederhana terhadap variabel Motivasi terhadap kinerja Pegawai di Badan
Pengelola Pajak Dan Retribusi Daerah Di Kota Lubuklinggau diperoleh persamaan regresi Kinerjapegawai $=7,951$ (Constant) + 1,562 (Motivasi). Dari persamaan regresi di atas, dapat dijelaskankan. Nilai konstanta yaitu sebesar 7,951. Hal ini menunjukan bahwa apabila variabel Kompensasi tidak ada atau nilainya nol, maka nilai dari kinerja pegawai adalah sebesar 7,951. Nilai koefisien regresi variabel Kompensasi sebesar 1,562 satuan, hal ini menunjukan bahwa apabila nilai variabel Kompensasi meningkat sebesar satu satuan, maka nilai variabel Kompensasiakan mengalami perubahan secara positif sebesar 1,562 satuan. Sebaliknya jika nilai regresi Kompensasi turun sebesar satu satuan, maka kinerja pegawai juga diprediksikan mengalami penurunan sebesar 1,562satuan. Oleh karena itu dapat disimpulkan bahwa Kompensasimempunyai hubungan yang searah terhadap kinerja pegawai. Hubungan erat di antara Kompensasi dengan kinerja pegawai dalam penelitian ini dapat dibuktikan melalui hasil uji koefisien korelasi (r) variabel bebas Kompensasi $\left(\mathrm{X}_{3}\right)$ yang diperoleh adalah 0,657 . Hal ini dapat diartikan bahwa hubungan antara variabel bebas Kompensasi $\left(\mathrm{X}_{3}\right)$ dan variabel terikat Kinerja (Y) secara parsial dapat dikatakan Kuat yaitu sebesar 0,657 karena nilai $r$ berada di interval koefisien 0,60 0,799.Hasil uji hipotesis ketujuhvariabel Kompensasi $\left(\mathrm{X}_{3}\right)$ terhadap kinerja pegawai menunjukan nilai thitung $=5,222$ lebih besar dari nilai ttabel1.687dengan tingkat signifikan $=0,000<(\alpha) 0.05, \mathrm{df}(\mathrm{n}-1) 38-1$ $=37$ adalah sebesar 1.687 hal ini menunjukan Ho ditolak dan Ha diterima dan secara parsial variabel Kompensasi memiliki pengaruh yang signifikan terhadap Kinerja Pegawai di Badan Pengelola Pajak Dan Retribusi Daerah Di Kota Lubuklinggau Hasil uji t ini membuktikan bahwa, hipotesis ketujuh penelitian ini yaitu "Ada pengaruh signifikan dari Kompensasi secara parsial terhadap kinerja pegawai Badan Pengelola 
Pajak Dan Retribusi Daerah Di Kota Lubuklinggauterbukti kebenarannya dan hipotesis diterima

\section{KESIMPULAN}

Hasil penelitian yang dilakukan oleh peneliti variabel yang memperngaruhi secara simultan yang paling dominan adalah variabel motivasi dan kompensasi terhadap kinerja pegawai maka dari itu jika kedua variabel ini dilakukan perubahaan secara bersama-sama maka kinerja pegawai akan meningkat secara optimal. dengan cara selalu memberikan motivasi kepada setiap pegawai seperti memberikan penghargaan atau pujian kepada pegawai yang telah menyelesaikan pekerjaannya dengan baik, selain motivasi kompesasi yang diterima pegawai juga harus diperhatikan oleh pimpinan apabila pegawai yang berprestasi diberikan kompensai yang sesuai maka pegawai akan merasa apa yang telah pegawai capai tidak sia-sia, maka dari itu hendaknya pimpinan memperhatikan kedua variabel diatas untuk menjadi ajuan di Badan Pengelola Pajak Dan Retribusi Daerah Di Kota Lubuklinggau.

Secara parsial menunjukan bahwa masing-masing variabel mempengaruhi kinerja pegawai di Badan Pengelola Pajak Dan Retribusi Daerah Di Kota Lubuklinggau., namun variabel kompensasi berpengaruh paling dominan, untuk itu perlu adanya dukungan dari setiap variabel, guna mewujudkan kinerja pegawai. Maka dari itu penelitian mengambil kesimpulan apabila pimpinan atau lembaga di Pemerintah khususnya Badan Pengelola Pajak Dan Retribusi Daerah Di Kota Lubuklinggau memperhatikan kebutuhan pegawai tentang kompensasi yang diterima pegawai maka kinerja pegawai akan meningkat sedangkan apabila pimpinan atau lembaga pemerintahan khususnya Badan Pengelola Pajak Dan Retribusi Daerah Di Kota Lubuklinggau tidak memperhatikan kebutuhan yang dimilki pegawai maka hasil kinerja pegawai tidak akan meningkat.

\section{SARAN}

Berdasarkan analisis dan kesimpulan pada bagian sebelumnya penelitian ini memperoleh beberapa bukti empiris yang dapat dijadikan masukan bagi Lembaga Pemerintahan, khususnya Badan Pengelola Pajak Dan Retribusi Daerah Di Kota Lubuklinggau Secara simultan kinerja pegawai di Badan Pengelola Pajak Dan Retribusi Daerah Di Kota Lubuklinggau dipengaruhi oleh Kepemimpinan, motivasi dan kompensasi yang diterima oleh pegawai belum sesuai dengan keinginan pegawai, maka implikasinya adalah untuk mewujudkan kinerja pegawai yang dimiliki Badan Pengelola Pajak Dan Retribusi Daerah Di Kota Lubuklinggau.

\section{DAFTAR PUSTAKA}

[1] Afandi, Pandi. (2018). Manajemen Sumber Daya Manusia (teori, konseo dan indikator). Yogyakarta: Nusa Meddia Yogyakarta.

[2] Aqila, Arta.(2019). Rangkuman Teori Manajemen SDM. https://artaqila.blogspot.co.id/2019/r angkuman-teori-manajemensdm.html tanggal akses : 29/02/2020.

[3] Besar, wahyu bagaswara. (2017). Pengaruh kompensasi, motivasi kerja, dan kepemimpinan terhadap kinerja karyawan (studi di pt asuransi jiwa syariah bumiputera syariah yogyakarta).

[4] Edison. (2016). Manajemen Sumber Daya Manusia. Jakarta: Erlangga.

[5] Effendi,Sofian. (2014). Metodolgi Effendi. Jakarta. Penerbit LP3ES, Anggota Ikapi.

[6] Ernie dan Jonni, (2018). Kepemimpinan dan Perilaku 
Organisasi : Membangun Organisasi Unggul di Era Perubahan. Bandung : PT. Refika Aditama.

[7] Fahmi, Irham. (2014). Manajemen, Teori, Kasus, dan Solusi. Bandung: Penerbit Alfabeta.

[8]

sumber daya manusia:Teori dan Aplikasi. Bandung: PenerbitCV. Alfabeta.

[9] Ghaffari, Sara.Dkk.(2017). "The Influence of Motivation on Job Performance: A Case Study at Universiti Teknologi Malaysia".

[10] Hamali, Arif Yusup. (2018). Pemahaman Manajemen Sumber Daya Manusia. Yogyakarta:CAPS.

[11] Handoko, T.Hani. (2014). Manajemen Personalia dan Sumber Daya Manusia. Yogyakarta:BPFE.

[12] Hasibuan, Malayu S P. (2014). Manajemen Sumber Daya Manusia. Jakarta: PT. Bumi Aksara Sumber Daya Manusia, Edisi Revisi, PT. Gelora Aksara Pratama, Jakarta.

[14] ------. (2019). Cetakan Kedua Puluh : Manajemen Sumber Daya Manusia. Jakarta: PT. Bumi Aksara.

[15] Muhidin, Sambas Ali. dan Abdurrahman, Maman. (2017). Analisis Korelasi, Regresi, Dan Jalur Dalam Penelitian. Bandung : Pustaka Setia.

[16] Nurdian, Desi, Dkk.(2016). "Pengaruh Kepemimpinan, Kompensasi, Motivasi Dan
Komitmen Organisasi Terhadap Kinerja Karyawan (Studi Kasus pada Karyawan PT. Indomarco Prismatama Cabang Malang).

[17] Kadarisman.(2014). Manajemen Pengembangan Sumber daya manusia. Jakarta:PT. Grafindo Persada.

[18] Khotimah, Kusnul.(2015). Pengaruh kepemimpinan, motivasi dan kompensasi Terhadap kinerja karyawan di PT PLN Area kediri.

[19] Mangkunegara, Anwar Prabu. (2017). Manajemen Sumber Daya Manusia Perusahaan. Bandung:PT.Remaja Rosdakarya.

[20] Lubis,Syafriyadi Miftahul Munir dan Arifa, Dian Afif.(2018). Pengaruh Kepemimpinan, Kompensasi, Budaya Organisasi dan Motivasi Kerja Terhadap Kinerja Karyawan Pt. Indo Kaya Energi".

[21] Republik, Indonesia. (2014). Undang-undang Nomor 5 Tentang Aparatur Sipil Negara. Jakarta: Sekretariat Negara.

[22] Selviasari, Rike.(2019). "The Effect Of Situational Leadership Style, Compensation and Motivation On Employee Performance In PT. Bank Rakyat Indonesia (Persero), Tbk. Kediri Branch".

[23] Sedarmayanti. 2014. Manajemen Sumber Daya Manusia. Bandung : PT Refika Aditama. 
[25] ---Manajemen

Sumber Daya Manusia, Cetakan ke

5. Bandung, PT. Refika Aditama.

[26] Siagian, Sondang. P. (2013).ManajemenSumberDayaMan usia. Jakarta: BumiAksara.

[27] Syofian Siregar. (2017).Statistik Parametrik untuk Penelitian Kuantitatif Dilengkapi dengan Perhitungan Manual dan Aplikasi SPSS Versi 17. Jakarta :BumiAksara.

[28] Sugiyono. (2013).Metode Penelitian Kuantitatif, Kualitati Dan $R \& D$. Bandung:Alfabeta. ----------(2013). Metode Penelitian Administrasi. Bandung : Alfabeta.

---------(2016). Metode

Penelitian Pendidikan Pendekatan, Kuantitatif, Kualitatif, dan $R \& D$. Bandung :Alfabeta.

[31] Sutrisno, Edy. (2016). Manajemen Sumber Daya Manusia. Jakarta : Kencana Prenada Media Group.

[32] Priansa, Donni Juni. (2017). Perencanaan dan Pengembangan Sumber daya manusia. Bandung:Alfabeta.

[33] Widodo,Djoko Setyo. (2017). "Pengaruh Budaya Organisasi, Kepemimpinan Dan Kompensasi Melalui Motivasi Kerja Terhadap Kinerja Pegawai".

[34] Wibowo. (2017). Edisi Kelima : Manajemen Kinerja. Depok:Penerbit PT Rajagrafindo Persada.
Organisasi. Jakarta : PT Raja grafindo Persada.

[36] Uha, Ismail Nawawi. (2015). Budaya Organisasi, Kepemimpinan, dan Kinerja. Jakarta: Prenadamedia Grup. 